\title{
Antioxidant and anti-inflammatory activity of extracts from red beet (Beta vulagaris) root
}

\author{
Mi-Ran $\mathrm{Yi}^{1}$, Kang Chang-Hee ${ }^{1,2}$, Hee-Jung $\mathrm{Bu}^{1 *}$ \\ ${ }^{1}$ Biotechnology Regional Innovation Center, Jeju National University, Jeju 63243, Korea \\ ${ }^{2}$ Department of Chemistry and Cosmetics, Jeju National University, Jeju 63243, Korea
}

레드 비트 뿌리 추출물의 항산화 및 항염증 효과

\author{
이미란 ${ }^{1} \cdot$ 강창희 $^{1,2} \cdot$ 부희정 $^{1 *}$ \\ ${ }^{1}$ 제주대학교 생명과학기술혁신센터, ${ }^{2}$ 제주대학교 화학.코스메틱스학과
}

\begin{abstract}
This study was designed to examine the in vitro antioxidant and anti-inflammatory effects of red beet (Beta vulagaris) root. Red beet root was extracted using $\mathbf{7 0} \%$ ethanol and then fractionated sequentially with $n$-hexane, ethyl acetate and butanol. Antioxidative ability was evaluated by bioassays using total polyphenol contents and ABTS (2,2'-azino-bis (3-ethylbenzothiazoline-6-sulphonic acid diammonium salt) radical scavenging activity. Ethyl acetate fraction of red beet root was best on total polyphenol contents $(37.02 \pm 0.37 \mathrm{mg} \mathrm{GAE} / \mathrm{g})$ and ABTS radical scavenging effects $\left(\mathrm{IC}_{50} 42.9 \pm 9.5 \mathrm{\mu g} / \mathrm{mL}\right)$. For the anti-inflammatory activity in RAW264.7 cells, the hexane fraction showed the highest inflammatory effect. Dose response studies were performed to determine the inhibitory effect of hexane fraction of red beet root on pro-inflammatory mediators in lipopolysaccharide (LPS)-stimulated RAW264.7 cells. The hexane fraction of red beet root inhibited the NO and $\mathrm{PGE}_{2}$ production and the protein level of iNOS and COX-2, and protein expression of pro-inflammatory cytokines (TNF- $a$, IL-6 and IL-1 $\beta$ ), in a dose-dependent manner. These results suggest that red beet root has considerable potential as a functional food ingredient with antioxidative and anti- inflammatory effects.
\end{abstract}

Key words : antioxidant, anti-inflammatory, nitric oxide, Beta vulagaris

\section{서 론}

산업사회가 발달하고 고령화 인구가 증가하면서 건강하 게 나이를 먹고자 하는 욕구가 증가하고 있고, 국민 생활이 향상되면서 건강 지향적인 식생활 패턴의 변화와 함께 건강 을 유지할 수 있는 기능성 식품이나 유효성이 탁월한 제품 들에 대한 소비자 관심이 커지고 있다. 이에 건강 기능성 식품 및 소재에 대한 연구 개발이 필수적이게 되었고 특히, 친환경적인 소재를 활용한 제품에 대한 구매 욕구가 증가하

*Corresponding author. E-mail : tang006@nate.com Phone : 82-64-754-2138, Fax : 064-726-3539

Received 29 March 2017; Revised 8 May 2017; Accepted 11 May 2017.

Copyright (c) The Korean Society of Food Preservation. All rights reserved.
게 되면서 천연소재로부터 생리활성 기능을 나타내는 물질 을 찾고자 하는 연구들이 활발하게 진행되고 있다(1). 그 중에서도 활성산소(reactive oxygen species, ROS)가 인체에 미치는 여러 가지 질환들에 대한 관심이 증가하면서 항산화 제에 대한 연구가 크게 증가하고 있다. 자외선, 질병상태, 공해물질, 화학약품, 신체적 정신적인 스트레스 증가 등의 각종 물리적 화학적, 환경적 요인 등에 의해 과도하게 생성 된 ROS는 지질 과산화, 단백질 산화, 단백질 분해효소의 활성화, DNA 산화와 같은 손상을 야기한다. 이러한 손상의 결과로 고혈압, 협심증, 당뇨병, 암, 동명경화, 파킨슨병, 뇌졸중 등과 같은 성인병 및 아토피성 피부염과 같은 염증 성 질환이 발생하게 된다(2-4). 따라서 활성산소 소거활성 을 갖는 항산화 소재는 매우 중요하고 다양하게 연구되어지 고 있다. 활성산소의 하나이면서 독성을 가진 매우 불안한 기체이며 고농도에는 세포의 기질적 손상을 초래하는 nitric 
oxide(NO)는 염증 반응 시에 inducible NO synthase(iNOS) 에 의해 과도하게 생성되어 혈관투과성, 부종 등의 염증반 응을 촉진시켜 염증을 심화시키게 된다(5). 염증반응은 인 체에 외부 병원체 등의 각종 외부 물질의 침입을 식별하고 이를 제거하여 항상성을 유지하는 자기방어체계인 1 차적 면역반응이다(6). 대식 세포는 염증 반응에서 방어적인 역 할을 수행하는 혈액 단핵세포로부터 분화한 조직 세포 로서, 그람 음성세균의 세포외막에 존재하는 내독소 lipopolysaccharide(LPS)에 의해 tumor necrosis factor-a (TNF-a), interleukin-6(IL-6), 및 interleukin-1B(IL-1ß) 등과 같은 염증성 cytokine의 분비를 증가시킨다(7). 또한 iNOS 에 의해 생성되는 $\mathrm{NO}$ 와 cyclooxygenase-2(COX-2)에 의해 서 생성되는 prostaglandin $\mathrm{E}_{2}\left(\mathrm{PGE}_{2}\right)$ 등의 염증유발인자들 도 생성된다 (8,9). 이러한 염증유발인자들은 $\mathrm{NO}$ 및 $\mathrm{ROS}$ 의 생성을 더 자극하게 되고 염증 반응이 과도해지게 되면 동맥경화증, 류마티즈 관절염, 천식, 기관지염, 다발성 경화 증 등 유발의 원인이 됨으로 이러한 만성질환의 예방 및 치료를 위하여 항산화 및 항염증 효과가 있는 소재의 개발 이 중요시되고 있다(10).

레드 비트(Beta Vulagaris)는 명아주과의 두해살이풀로 유럽 남부가 원산지이며 고대 로마시대부터 이용되어 온 식물로 잎과 뿌리 모두 식용할 수 있어 외국에서는 집에서 손쉽게 재배하는 인기작물이다. 기후가 따뜻한 곳에서 많 이 생산되는 비트는 우리나라에서는 제주도 지방에서 잘 자란다. 비트에는 칼로리가 낮고 각종 미네랄과 비타민이 풍부하여 다양하게 건상상의 유익함을 줄 수 있는 식물이 다. 음식으로는 샐러드나 장아찌, 물김치, 피클 등으로 많이 활용되고 있고, 미국과 유럽 등지에서는 주스나 정제로 만 들어 건강기능성 식품으로 판매하기도 한다. 레드 비트의 생리활성으로는 심혈관계, 면역계, 대사성 질환 및 빈혈과 변비 등에도 좋다고 알려져 있으며, 레드 비트에 들어있는 안토시아닌(anthocyanin)과 베타닌(betanin) 등의 색소 성분 에는 항산화 및 항암 효과가 보고되어 있다(11-16).

본 연구에서는 제주산 레드 비트 추출물을 대상으로 항 산화 및 항염증 활성을 갖는 기능성 식품 소재 자원으로 활용 가치가 있는지 극성에 따라 순차적으로 용매 분획을 하여 시험에 사용하였다. 제작된 $70 \%$ ethanol(EtOH) 추출 물과 용매 분획물들의 총 폴리페놀 함량 및 $\mathrm{ABTS}$ 라디칼 소거 활성 평가를 통하여 항산화 효능을 갖는 분획물을 확인하였고, 염증성 매개인자인 $\mathrm{NO}, \mathrm{PGE}_{2}$ 의 생성 억제 및 이를 합성하는 iNOS와 COX-2 단백질 발현 억제와 염증성 cytokine 억제 효과를 측정하여 유의한 결과를 얻었기에 보고하는 바이다.

\section{재료 및 방법}

실험재료 및 추출물의 제조

레드 비트 뿌리는 2015년 2월에 유기농으로 재배되어
수확된 것을 제주도 친환경 농산물 유통 업체인 생드르 영농조합법인에서 같은 해 3 월에 구입한 것을 사용하였다. 구입한 시료를 $40^{\circ} \mathrm{C}$ 에서 3 일간 열풍 건조하여 얻어진 시료 $250 \mathrm{~g}$ 분말을 20 배의 $70 \% \mathrm{EtOH}$ 을 가하여 총 3 회 추출하였 으며, 감압 농축하여 $70 \% \mathrm{EtOH}$ 조추출물 $150 \mathrm{~g}$ 을 얻었다. 이 후 얻어진 조추출물을 증류수로 현탁시킨 후에 n-hexane $1 \mathrm{~L}$ 씩 3회, EtOAc $1 \mathrm{~L}$ 씩 3회, 그리고 butanol(BuOH) $1 \mathrm{~L}$ 씩 3 회로 순차적으로 분획 및 농축하여 각각의 분획물을 확보 한 후 동결 건조하고 $-20^{\circ} \mathrm{C}$ 에서 냉동 보관하면서 실험에 사용하였다(Fig. 1).

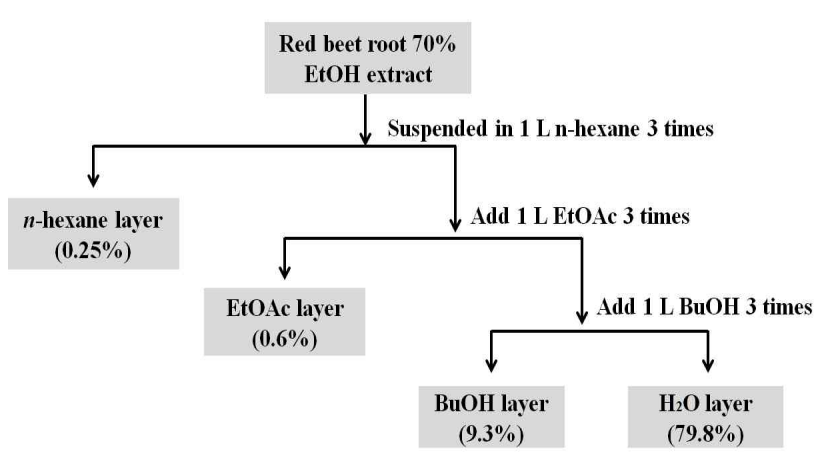

Fig. 1. Systematic purification using solvent partitioning from red beet root.

총 폴리페놀 함량 분석

총 폴리페놀 함량은 Folin-Denis 방법으로 측정하였다 (17). 실험 시료는 $70 \% \mathrm{EtOH}$ 에 $100 \mathrm{mg} / \mathrm{mL}$ 의 농도로 제조 하여 시료 용액 $200 \mu \mathrm{L}$ 와 증류수 $1,800 \mu \mathrm{L}$ 을 혼합하고, Folin-Ciocalteau's phenol reagent $200 \mu \mathrm{L}$ 을 가하여 잘 섞은 후 5 분간 상온에서 반응시켰다. 여기에 $2 \mathrm{M} \mathrm{Na}_{2} \mathrm{CO}_{3} 400$ $\mu \mathrm{L}$ 을 가하여 혼합한 다음 증류수를 가하여 $4 \mathrm{~mL}$ 로 조정하 였다. 이 용액을 상온 암소에서 1 시간 동안 반응시킨 후 $725 \mathrm{~nm}$ 에서 흡광도를 측정하였고, gallic acid(Sigma Chemical Co., St. Louis, MO, USA)를 이용한 검량선과 비교 하여 총 페놀함량을 $\mathrm{mg}$ gallic acid equivalents(GAE)/g로 나타내었다.

\section{ABTS 라디칼 소거활성}

라디칼 소거활성 측정을 위해 2,2'-azinobis(3ethylbenzothiazoline-6-sulfonic acid, ABTS)는 Re 등의 방법 을 변형하여 측정하였다(18). 시험 용액의 제조는 증류수에 $7 \mathrm{mM}$ ABTS와 $2.45 \mathrm{mM}$ potassium persulfate를 첨가하고, 상온에서 16 시간 배양하여 $\mathrm{ABTS}$ 양이온(ABTS ${ }^{+}$)을 생성시 켰다. $2.45 \mathrm{mM}$ potassium persulfate buffer와 동량 혼합하였 을 때, $734 \mathrm{~nm}$ 에서 흡광도의 값이 $0.70( \pm 0.02)$ 이 되도록 희석하여 제조하였다. 그 다음 시료의 여러 농도에 희석한 $\mathrm{ABTS}^{+}$용액을 동량 가하여 6 분 후에 흡광도 값을 측정하였 다. 대조군(2.45 mM potassium persulfate buffer)의 흡광도 
와 비교하여 흡광도를 감소시키는 정도를 \%로 나타내었으 며, 양성대조군으로는 ascorbic acid(Vit. C)와 BHT (dibutyl hydroxy toluene)를 사용하였다.

\section{세포배양}

Murine macrophage cell line 인 RAW264.7 세포는 한국세 포주은행(Korean Cell Line Bank)으로부터 구입하였으며 $10 \%$ fetal bovine serum(FBS)과 100 uint $/ \mathrm{mL}$ penicillinstretomycin(GIBCO Inc, New York, NY, USA)이 포함된 Dulbecco's Modified Eagle Medium(DMEM, GIBCO Inc, $\mathrm{NY}, \mathrm{USA})$ 배지를 사용하여 $37^{\circ} \mathrm{C}, 5 \% \mathrm{CO}_{2}$ 항온기에서 배양 하였다. LPS(E. coli serotype 0111:B4)는 Sigma로부터 구입 하여 사용하였다.

세포독성과 nitric oxide(NO) 생성 저해능 측정

24 Well plate에 RAW264.7 cells를 $2.5 \times 10^{5}$ cells $/ \mathrm{mL}$ 로 분주하고 $37^{\circ} \mathrm{C}, 5 \% \mathrm{CO}_{2}$ incubator 조건하에 18 시간 배양한 후 실험에 사용하였다. 전 배양시킨 cells을 $1 \mu \mathrm{g} / \mathrm{mL}$ LPS 가 포함된 배지로 교환 후, 시료를 농도별로 각각 첨가하여 24시간 배양하였다. 세포배양 상등액 $100 \mu \mathrm{L}$ 과 Griess 시약 (1\%(w/v) sulfanilamide, $0.1 \% \mathrm{~N}$-(1-naphyl) ethylenediamine (Sigma) in 2.5(v/v) phosphoric acid) $100 \mu \mathrm{L}$ 을 혼합하여 96 well plate에서 10 분 동안 반응시킨 후 $530 \mathrm{~nm}$ 에서 흡광도를 측정하였으며, 생성된 $\mathrm{NO}$ 의 양은 sodium nitrite $\left(\mathrm{NaNO}_{2}\right)$ 의 검량선과 비교하여 환산하였다(19).

세포독성 평가는 MTT[3-(4,5- dimethyl-thiazol-2-yl)-2,5diphenyl tetrazolium bromide] 법으로 세포 생존율을 3회 반복 측정하였으며, 시료의 농도에 대한 흡광도를 $570 \mathrm{~nm}$ 에서 측정한 후 대조군의 흡광도와 비교하여 RAW264.7 세포에 대한 독성 정도를 나타내었다.

Prostaglandin $\mathrm{E}_{2}\left(\mathrm{PGE}_{2}\right)$ 생성 억제 효능 평가

RAW264.7 cell을 $2.5 \times 10^{5}$ cells $/ \mathrm{mL}$ 되도록 24-well plate에 분주하고 $37^{\circ} \mathrm{C}, 5 \% \mathrm{CO}_{2}$ incubator에 전 배양한 다음 sample 과 LPS $1 \mu \mathrm{g} / \mathrm{mL}$ 와 함께 처리한 후 24시간 동안 배양 후 원심분리하여 상층액을 얻어 실험을 진행하였다. $\mathrm{PGE}_{2}$,의 측정은 mouse enzyme-linked immnunosorbent assay (ELISA) kit(R\&D system, Minneapolis, MN, USA)를 이용하 여 정 량하였으며, standard에 대한 표준곡선의 $\mathrm{r}^{2}$ 값은 0.99 이상이었다.

iNOS 및 COX-2 발현 억제 효능 평가(western-blotting)

RAW264.7 cell을 $5 \times 10^{5}$ cells $/ \mathrm{mL}$ 되도록 6-well plate에 18 시간 동안 $37^{\circ} \mathrm{C}, 5 \% \mathrm{CO}_{2}$ incubator에 전 배양하였다. 이 후 sample과 LPS $1 \mathrm{\mu g} / \mathrm{mL}$ 와 함께 처리한 후 24시간 동안 배양 후 배지를 제거하고 PBS로 세척한 후, lysis buffer로 세포를 용해하여 원심분리 $\left(22,072 \times \mathrm{g}, 20 \mathrm{~min}, 4^{\circ} \mathrm{C}\right)$ 하고 상
층액을 얻은 다음 단백질 농도를 측정하였다. 단백질 농도 는 bovine serum albumin(BSA)를 표준화하여 Bio-Rad Protein Assay Kit를 사용하여 정량하였다. 정량한 단백질을 4-12\%의 SDS-polyacrylamide gel에 전기영동하고 polyvinylidene difluoride(PVDF) membrane(BIO-RAD, Richmond, CA, $\mathrm{USA}$ )에 전이시켰다. 단백질이 전이된 membrane에 1 차 항 체인 iNOS antibody, COX-2 antibody, $\beta$-acitin antibody clone AC-74를 이용하여 반응시킨 후, 2 차 항체와 반응시켰 다. 단백질은 WEST-ZOL(western blot detection system, iNtRON, Seongnam, Korea) 용액을 이용해 ECL 기질과 반 응시킨 후, Chemidoc(Fusion solo, VILBER LOURMAT, Germany)을 이용하여 각각의 단백질 발현정도를 확인하였 다.

염증성 사이토카인(TNF-a, IL-6, IL-1ß) 생성 억제 효능 평가

RAW264.7 cell을 $2.5 \times 10^{5}$ cells $/ \mathrm{mL}$ 이 되도록 24-well plate에 18 시간 동안 $37^{\circ} \mathrm{C}, 5 \% \mathrm{CO}_{2}$ incubator에 배양한 다음 준비된 각각 농도의 sample과 LPS $1 \mathrm{\mu g} / \mathrm{mL}$ 와 함께 처리한 후 24시간 동안 배양 후 얻어진 상층액의 pro-inflammatory cytokines 생성 함량을 측정하였다. Pro-inflammatory cytokines 정량은 mouse enzyme-linked immnunosorbent assay(ELISA) kit(R\&D system)를 이용하여 정량하였으며, standard에 대한 표준곡선의 $\mathrm{r}^{2}$ 값은 0.99 이상이었다.

통계분석

모든 데이터는 평균표준편차로 표기하였고, 각 군의 차이는 분산분석, 사후검정은 다중범위 검정(Duncan's multiple range test)으로 실시하였고, 모든 통계자료는 SPSS 12 program(SPSS Inc., Chicago, IL, USA)을 이용하여 분석 하였다.

\section{결과 및 고찰}

\section{총 폴리페놀 함량 분석}

폴리페놀 화합물은 식물체에 널리 분포되어 있는 2 차 대사산물로 한 분자 내에 2개 이상의 phenolic hydroxyl $(-\mathrm{OH})$ 을 가지고 있어 여러 화합물과 쉽게 결합하는 특징을 갖고 있으며, 항산화, 항균, 항암, 항염, 항당뇨 등 다양한 생리활성을 가지고 있는 것으로 보고되고 있다 $(20,21)$. 식 물체에 들어있는 폴리페놀과 플라보노이드 함량이 많을수 록 항산화를 비롯한 생리활성이 커지는 경향으로 보고되어 $(22,23)$ 천연물의 항산화 활성을 검색하는 기초자료로 활용 할 수 있다. 따라서 레드 비트 뿌리 $70 \% \mathrm{EtOH}$ 추출물을 용매 분획하여 총 폴리페놀 함량을 측정한 결과 Table 1에 서와 같이 EtOAc 분획물과 $\mathrm{BuOH}$ 분획물이 다른 추출물에 
비해 각각 $37.02 \mathrm{mg} \mathrm{GAE} / \mathrm{g}, 23.51 \pm 0.22 \mathrm{mg} \mathrm{GAE} / \mathrm{g}$ 으로 높게 확인되었다. 이러한 결과로부터 비트 뿌리에 함유되어 있 는 phenol성 물질들이 용출되는 polarity를 확인할 수 있었 다.

Table 1. Total polyphenol contents of $70 \%$ EtOH extract and solvent fractions of red beet root

\begin{tabular}{cc}
\hline Material & mg gallic acid equivalents $(\mathrm{GAE}) / \mathrm{g}$ \\
\hline $70 \%$ EtOH & $7.01 \pm 0.04^{1)(\mathrm{c})}$ \\
Hexane & $4.99 \pm 0.08^{\mathrm{b}}$ \\
$\mathrm{EtOAc}$ & $37.02 \pm 0.37^{\mathrm{e}}$ \\
$\mathrm{BuOH}$ & $23.51 \pm 0.22^{\mathrm{d}}$ \\
$\mathrm{H}_{2} \mathrm{O}$ & $4.28 \pm 0.01^{\mathrm{a}}$ \\
\hline
\end{tabular}
1) Values are expressed as mean \pm SD of triplicate measurements.
${ }^{2)}$ Values with different letters (a-e) in the column are significantly different at $p<0.05$
according to Duncan's multiple range test.

\section{ABTS 라디칼 소거 활성}

라디칼 소거 활성과 총 폴리페놀 화합물의 함량사이에는 밀접한 상관관계가 있다는 연구 결과들에 근거하여 비트 각 분획물의 $\mathrm{ABTS}$ 라디칼 소거활성을 측정한 결과, 총폴리 페놀 함량의 결과와 같은 경향인 $\mathrm{EtOAc}>\mathrm{BuOH}>70 \%$ $\mathrm{EtOH}>\mathrm{Hexane}>\mathrm{H}_{2} \mathrm{O}$ 순으로 라디칼 소거 활성을 나타냄 (Table 2)을 확인함으로써 총 폴리페놀 함량이 높을수록 항산화 활성이 증가하는 비례적 상관관계를 확인 할 수 있었다. 폴리페놀 함량이 가장 높게 측정되었던 EtOAc 분 획물인 경우 $250 \mu \mathrm{g} / \mathrm{mL}$ 농도에서 $94.8 \%$ 로 높은 소거활성을 나타내었으며, 같은 농도에서 대조군으로 사용된 Vit. C( $100 \%), \mathrm{BHT}(98.5 \%)$ 와 유사한 활성을 보였다. 또한 자유 라디칼을 $50 \%$ 소거하는 $\mathrm{IC}_{50}$ 값 농도는 Vit. $\mathrm{C}\left(\mathrm{IC}_{50} ; 7.5\right.$ $\mu \mathrm{g} / \mathrm{mL})$ 보다는 낮지만 $\mathrm{BHT}\left(\mathrm{IC}_{50} ; 57.4 \mu \mathrm{g} / \mathrm{mL}\right.$ ) 보다 좋은 활성 $\left(\mathrm{IC}_{50} ; 42.9 \mu \mathrm{g} / \mathrm{mL}\right)$ 을 보였다. 이러한 결과는 Lee와 Chin(24)의 연구에서 비트 물추출과 $\mathrm{EtOH}$ 추출에서 $\mathrm{DPPH}$ 라디칼 소거활성을 $0.05 \%(500 \mathrm{\mu g} / \mathrm{mL})$ 의 농도에서 측정한 결과와 비교하였을 때, 본 연구에서 $70 \% \mathrm{EtOH}$ 이 동일 농도 에서 $77.7 \pm 1.2 \%$ 로 각각 약 1.7 배와 2.9 배 정도 높게 나타났 다. 이러한 활성의 차이는 시료 추출 방법과 실험방법의 차이에 기인한 것으로 사료된다. 일반적으로 같은 시료의 라디칼 소거 활성 측정을 할 때 $\mathrm{ABTS}$ 라디칼 소거 활성이 $\mathrm{DPPH}$ 라디칼 소거 활성 측정값보다 높게 나타난다고 보고 되어 있다(25). 즉, $\mathrm{ABTS}$ 의 경우 효소반응에 의하여 라디칼 이 생성되며 친수성 용매, 유기용매에 용해되어 친수성, 소수성 물질의 항산화 활성 측정에, $\mathrm{DPPH}$ 의 경우 자유라디 칼로 유기용매에 용해되어 실험에 사용하므로 친수성 물질 보다 항산화 효과가 있는 소수성 물질과 더 많이 반응하기 때문이다.

이러한 결과들로부터 레드 비트 뿌리의 EtOAc 분획물은
천연 항산화제로써 활용가치가 있을 것으로 여겨지며, 현 재까지 비트 뿌리에 대한 항산화 활성을 가지는 물질의 동정은 색소성분인 betanin 등 일부만 되어 있어 향후 $\mathrm{EtOAc}$ 및 $\mathrm{BuOH}$ 층에서 $\mathrm{ABTS}$ 라디칼 소거 활성을 가지는 물질의 동정이 필요할 것으로 사료된다.

Table 2. Effects of 70\% EtOH extract and solvent fractions of red beet root on ABTS radical scavenging activity

\begin{tabular}{ccc}
\hline \multirow{2}{*}{ Material } & \multicolumn{2}{c}{ ABTS radical scavenging activity } \\
\cline { 2 - 3 } & at $250 \mu \mathrm{g} / \mathrm{mL}(\%)$ & $\mathrm{IC}_{50}(\mu \mathrm{g} / \mathrm{mL})$ \\
\hline $70 \%$ EtOH & $32.9 \pm 0.8^{\mathrm{c} 12)}$ & $465.8 \pm 2.5^{\mathrm{d}}$ \\
Hexane & $29.3 \pm 0.0^{\mathrm{b}}$ & $894.0 \pm 26.4^{\mathrm{e}}$ \\
$\mathrm{EtOAc}$ & $94.8 \pm 0.2^{\mathrm{e}}$ & $42.9 \pm 9.5^{\mathrm{b}}$ \\
$\mathrm{BuOH}$ & $72.3 \pm 0.3^{\mathrm{d}}$ & $117.7 \pm 3.7^{\mathrm{c}}$ \\
$\mathrm{H}_{2} \mathrm{O}$ & $19.9 \pm 0.2^{\mathrm{a}}$ & $967.4 \pm 6.6^{\mathrm{f}}$ \\
Vit. C & $100.0 \pm 0.0$ & $7.5 \pm 0.1^{\mathrm{a}}$ \\
BHT & $98.5 \pm 0.1^{\mathrm{f}}$ & $57.4 \pm 1.1^{\mathrm{b}}$ \\
\hline
\end{tabular}

${ }^{1)}$ Values are expressed as mean $\pm \mathrm{SD}$ of triplicate measurements.

${ }^{2)}$ Values with different letters (a-f) in the column are significantly different at $p<0.05$ according to Duncan's multiple range test.

${ }^{3)}$ Positive control: Vit. C, ascorbic acid; BHT, dibutyl hydroxy toluene.

세포독성과 NO 생성 저해능

자외선, 스트레스, 공해 등과 같은 환경요인에 의해 과다 생성되어 염증 유발에 중요한 역할을 하는 것으로 알려져 있는 NO 억제 효능을 측정하기 위하여 LPS를 RAW264.7 세포에 처리하여 과다 유도 발생시켜 비트 분획물들을 처리 하였다. 실험 결과, hexane 분획물에서 $69.5 \%$ 로 세포 독성 이 없이 NO 생성 억제 활성이 가장 높았다(Fig. 2A). 그러나 총 폴리페놀 함량과 라디칼 소거 활성이 가장 좋았던 $\mathrm{EtOAc}$ 분획물은 $93 \%$ 의 세포 생존율과 $36.3 \%$ 의 NO 억제 효과를 나타내 총폴리페놀 함량 및 항산화 효과와 $\mathrm{NO}$ 억제 효과는 유의적인 상관관계가 없음을 확인하였다. 가장 좋 은 NO 억제 효과를 보인 hexane 분획물을 $50,100,200$, $300 \mu \mathrm{g} / \mathrm{mL}$ 의 농도로 처리하여 NO 억제 활성을 확인한 결과 농도 의존적으로 NO 생성을 억제되는 것을 확인할 수 있었 다. 이러한 결과는 최근 Lee 등(26)의 식용식품의 항산화, 항염 효과에 대한 연구 결과에 의하면 세포 생존률이 $95 \%$ 이상인 $1,000 \mathrm{\mu g} / \mathrm{mL}$ 의 농도에서 가장 좋은 효능을 보인 배암차즈기(Salvia plebeia R. Br.) 상층부의 NO 억제 효과 (67.4\%)와 같은 뿌리 채소인 무(Raphanus sativus)의 NO 억제 효과(36.6\%)보다도 훨씬 낮은 농도에서 좋은 효과로 식용 작물로써 레드 비트 뿌리가 항염 소재로서의 활용 가능성이 높음을 확인하였다.

세포독성 확인을 위한 MTT 실험법은 같은 처리 조건에 서 동시에 측정하였고, 가장 높은 농도인 $300 \mathrm{\mu g} / \mathrm{mL}$ 의 농도 에서도 $92.4 \%$ 세포 생존율로 세포독성이 거의 나타나지 않으면서 $94.7 \%$ 의 강한 NO 생성 억제 효과를 나타내어 
(Fig. 2B) 동일 농도 조건에서 hexane 분획물의 $\mathrm{PGE}_{2}$, cytokines, iNOS 및 COX-2 발현 억제 실험을 진행하였다.

(A)

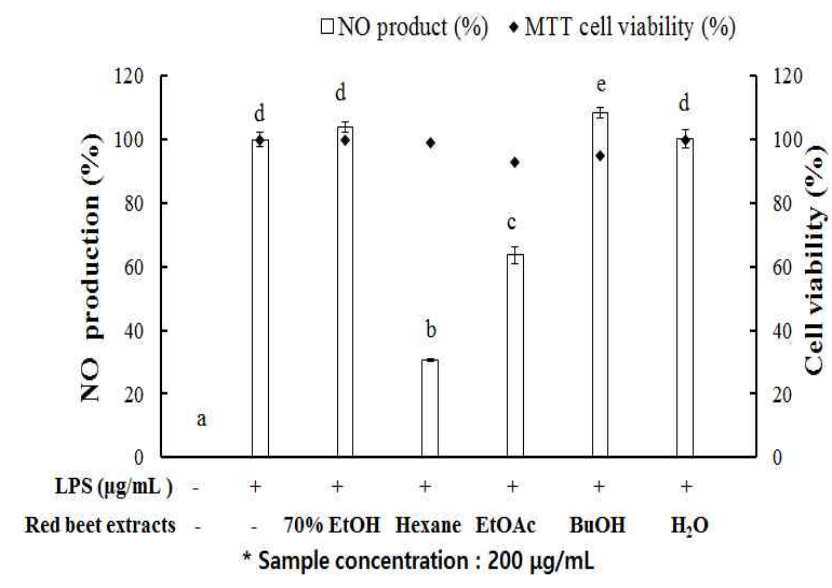

(B)

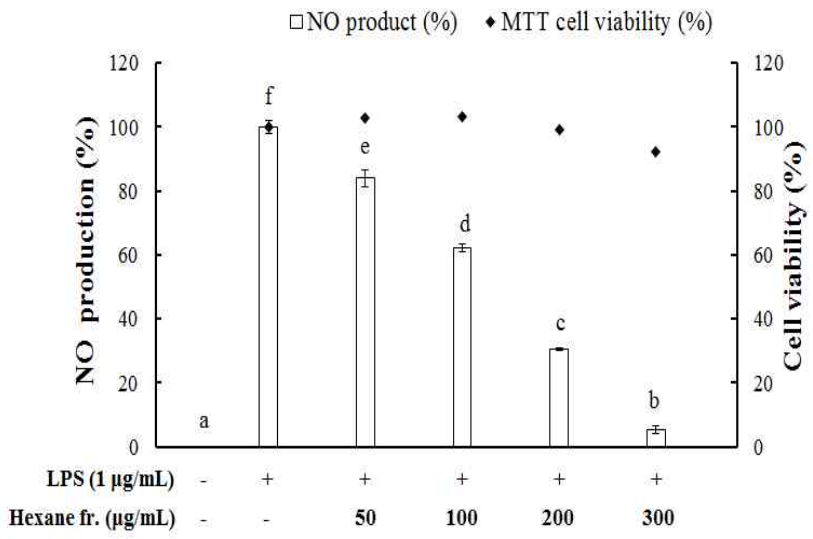

Fig. 2. Cell viability and inhibitory activity of nitric oxide production in RAW264.7 cells.

The production of NO was assayed in the culture medium of cells stimulated with LPS $(1 \mathrm{\mu g} / \mathrm{mL})$ for $24 \mathrm{~h}$ in the presence of the samples. Cell viability was determined using the MTT method.

Values are expressed as mean $\pm \mathrm{SD}$ of triplicate measurements. Values with different letters (a-f) are significantly different at $p<0.05$ according to Duncan's multiple range test.

\section{Prostaglandin $\mathrm{E}_{2}\left(\mathrm{PGE}_{2}\right)$ 생성 억제 효과}

Prostaglandin $\mathrm{E}_{2}\left(\mathrm{PGE}_{2}\right)$ 는 잘 알려진 염증유발 인자로서 통증 및 혈관의 확장과 대식세포 등 면역세포를 염증 부위 로의 이동에 관여하는 것으로 알려져 있다. $\mathrm{NO}$ 억제 활성에 서 가장 좋은 효능을 보였던 hexane 분획물에서 LPS에 의해 유도 증가된 $\mathrm{PGE}_{2}$ 생성에 대한 억제효능을 확인하였다. 실험결과, LPS 단독처리군에 비해 실험군 $300 \mu \mathrm{g} / \mathrm{mL}$ 의 농 도에서 $85 \%$ 의 억제 효과를 보였고, $\mathrm{NO}$ 억제 결과와 유사하 게 농도 의존적으로 염증성 $\mathrm{PGE}_{2}$ 의 생성을 효과적으로 억 제하는 것을 확인할 수 있었다(Fig. 3). 이러한 결과들은 레드 비트 뿌리 hexane 추출물이 $\mathrm{NO}$ 와 $\mathrm{PGE}_{2}$ 의 생성 조절을
통해 항염증 효과를 나타낼 수 있다는 것을 보여준다.

RAW264.7 세포에서 iNOS, COX-2 생성 억제 효과 염증반응에서 $\mathrm{NO}$ 및 $\mathrm{PGE}_{2}$ 의 생성은 염증반응에 관여하 는 효소인 iNOS 및 COX-2에 의해 각각 조절된다. iNOS는 평소에는 세포 내에 존재하지 않으나 일단 유도되면 장시간 동안 다량의 $\mathrm{NO}$ 를 생성하며, 생성된 $\mathrm{NO}$ 는 혈관확장, 세포 독성, 조직손상 등과 같은 생체에 유해한 작용을 나타내는 대표적인 염증자극에 반응하여 유도되는 단백질로 iNOS 발현증가를 억제함으로써 항염증반응에 관여할 수 있다. $\mathrm{COX}-2$ 는 arachidonic acid로부터 $\mathrm{PGE}_{2}$ 를 생성하는데 관여 하는 효소로서, 염증반응을 조절하는 중요한 단계로 작용 한다. 염증상태에서 $\mathrm{iNOS}$ 와 $\mathrm{COX}-2$ 에 의해 생성된 $\mathrm{NO}$ 와 $\mathrm{PGE}_{2}$ 는 혈관 투과성, 부종 및 통증 등의 초기 염증반응을 촉진하고 염증매개체의 생합성을 촉진하여 염증을 심화시 켜 만성 질환을 일으키는 것으로 알려져 있다 $(27,28)$. 현재 임상적으로 상용되고 있는 NSAID(non-steroidal inflammatory drug) 항염증 치료제들은 COX-2 발현 억제를 통해 항염증 효과를 발휘하는 것으로 알려져 있다. 따라서 본 연구에서 도 레드 비트 뿌리의 hexane 분획물에서 LPS에 의해 유도 증가된 $\mathrm{NO}$ 및 $\mathrm{PGE}_{2}$ 생성에 대한 억제효과가 $\mathrm{iNOS}$ 및 COX-2 효소의 발현 조절에 의한 것인지 확인하기위하여 단백질 수준에서의 발현을 western blot analysis로 확인하였 다. 실험 결과, iNOS와 COX-2 단백질 발현 억제 활성을 모두 농도 의존적으로 보이고 있음을 알 수 있으며, 특히 $\mathrm{iNOS}$ 인 경우 $200 \mu \mathrm{g} / \mathrm{mL}$ 에서 경우 세포 독성이 없이 $96.8 \%$ 의 억제 효과를, 같은 농도에서 $\mathrm{COX}-2$ 는 $37.5 \%$ 의 억제 효과를 보였다(Fig. 4). 이러한 결과들로부터 비트 헥산 추

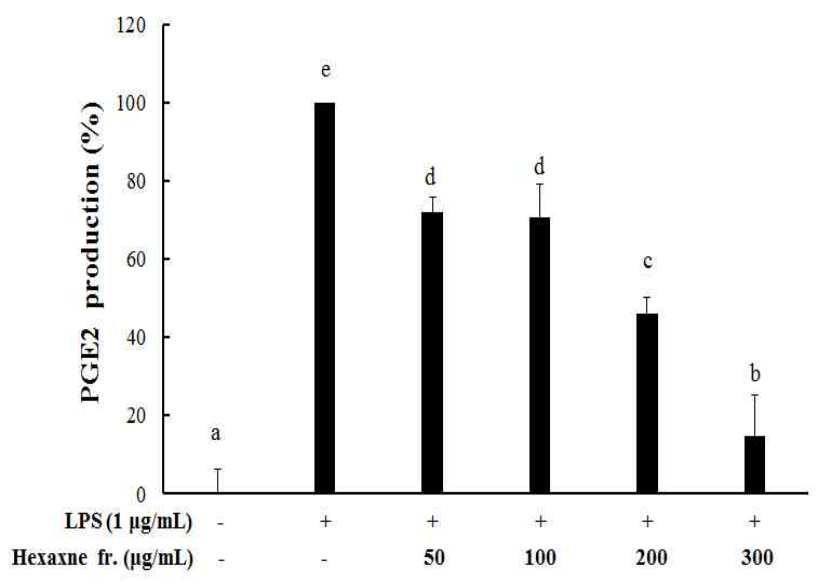

Fig. 3. Inhibitory effects of hexane fraction of red beet root on PGE2 production in RAW264.7 cells.

Cells $\left(2.5 \times 10^{5}\right.$ cells $\left./ \mathrm{mL}\right)$ were stimulated by LPS $(1 \mu \mathrm{g} / \mathrm{mL})$ for $24 \mathrm{~h}$ in the presence of $70 \% \mathrm{EtOH}$ extracts and solvent fraction of red beet root. Supernatant was determined by ELISA.

Values are mean \pm SEM of triplicate experiments. Values with different letters (a-e) are significantly different at $\mathrm{p}<0.05$ according to Duncan's multiple range test. 


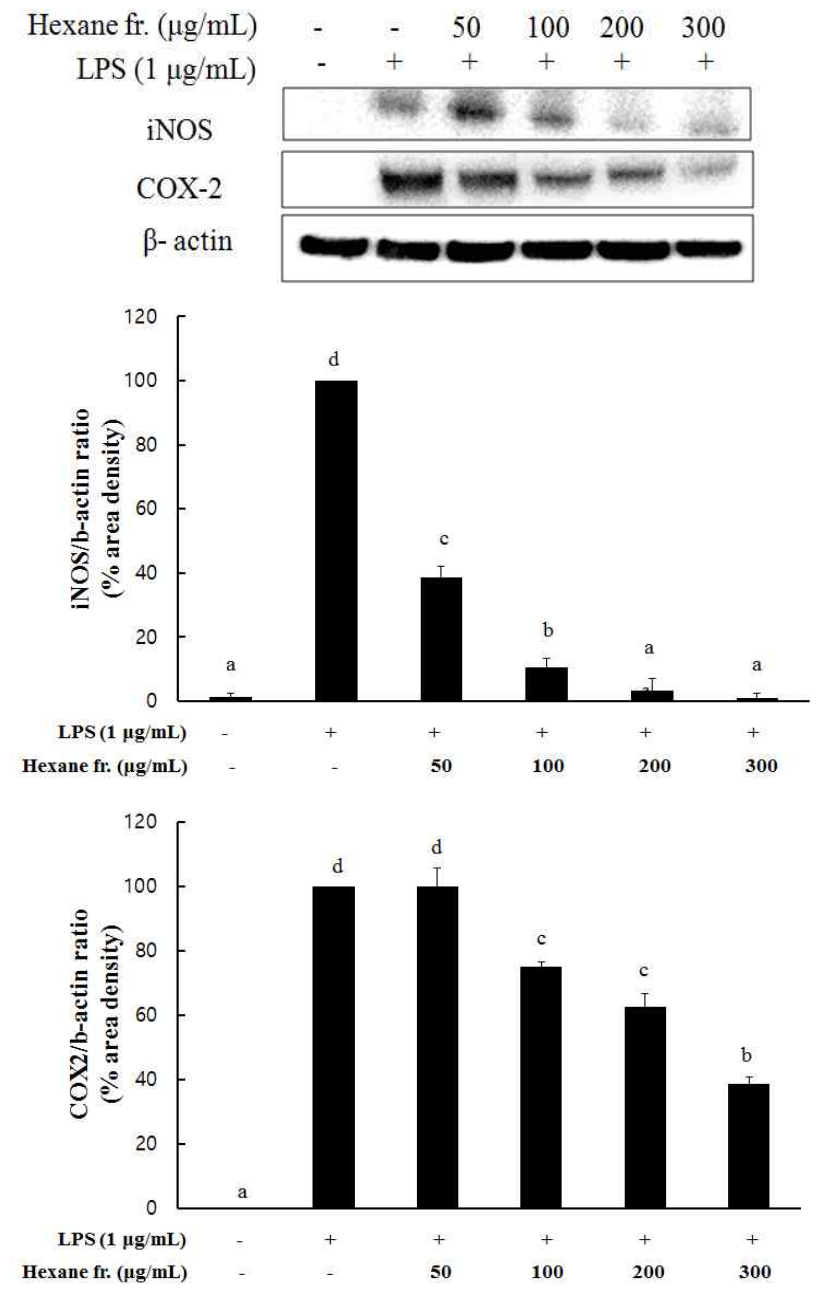

Fig. 4. Inhibitory effects of hexane and ethyl acetate fraction of red beet root on iNOS and COX-2 protein expression in LPS-stimulated RAW264.7 cells.

Cells $\left(5 \times 10^{5} \mathrm{cells} / \mathrm{mL}\right)$ were pre-incubated for $18 \mathrm{~h}$, and then cells were stimulated with LPS $(1 \mu \mathrm{g} / \mathrm{mL})$ for in the presence of the samples. The expression levels of iNOS and COX-2 protein were determined by immunoblotting.

Values are the mean \pm SEM of triplicate experiments. Values with different letters (a-d) are significantly different at $p<0.05$ according to Duncan's multiple range test.

(A)

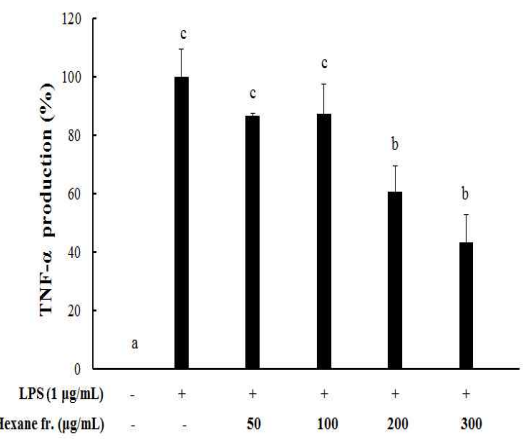

(B)

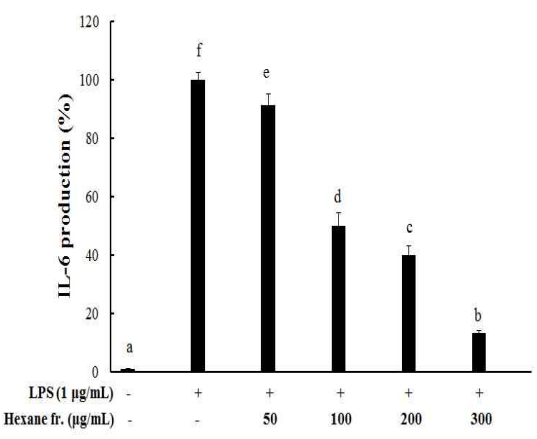

출물의 $\mathrm{NO}$ 및 $\mathrm{PGE}_{2}$ 생성 억제는 $\mathrm{iNOS}$ 와 $\mathrm{COX}-2$ 단백질 발현을 억제시킴으로써 나타나는 결과임을 알 수 있었고, $\mathrm{COX}-2$ 에 의한 $\mathrm{PGE}_{2}$ 합성 억제 보다는 $\mathrm{iNOS}$ 발현 억제를 통한 NO 생성 억제 효과가 더 큼을 확인할 수 있었다. 또한 비트 뿌리의 항염 효능은 식용 가능한 과채류로서 최근 Kim 등(29)의 과일류인 병귤의 항염증 효과 연구에서 가장 활성이 좋은 9월에 수확된 병귤 과피의 iNOS 발현 억제 효과 $(80 \%)$ 보다도 좋은 것으로 비트 뿌리가 항염 효능을 갖는 식품 소재로서 충분히 이용가능성이 있을 것으로 사료 된다.

염증성 사이토카인(TNF-a, IL-6, IL-1 $\beta$ ) 생성 억제 효과

Cytokine은 면역세포가 분비하는 단백질로서 면역세포 의 활성, 증식 및 분화를 조절하여 염증반응을 매개하는 인자로, 염증성 질환의 원인과 치료를 규명하기 위하여 cytokine의 역할이 중요시 되고 있다. TNF- $a, \mathrm{IL}-6$ 및 $\mathrm{IL}-1 \beta$ 는 대표적인 pro-inflammatory cytokine로 LPS로 자극된 RAW264.7 세포는 비처리군에 비하여 염증성 cytokine의 분비를 증가시켰으며, 비트 hexane 분획물의 처리로 증가된 TNF-a, IL-6 및 IL-1 $\beta$ 의 생성이 모두 농도 의존적으로 억제 됨을 확인할 수 있었다(Fig. 5). 가장 높은 농도인 $300 \mu \mathrm{\mu g} / \mathrm{mL}$ 의 농도에서는 각각 $57,87,51 \%$ 로 모두 $50 \%$ 이상의 저해 활성을 나타내었다. 특히, 과잉 생산 시 여러 가지 면역이상 증, 염증성 질환, 림프계 종양의 발증과 깊은 관련이 있는 것으로 알려져 있는 IL-6에 대하여서는 $100 \mu \mathrm{gg} / \mathrm{mL}$ 의 농도 부터 $50 \%$ 이상의 저해 효과를 보였다. 이러한 결과들로부 터 레드 비트 뿌리 hexane 분획물이 TNF-a 및 IL-1B에 비해 IL-6의 억제를 통한 항염 효능이 클 것으로 예측할 수 있었 다(Fig. 5B).

종합적으로 레드 비트 뿌리의 항산화 효능은 일반적으로 폴리페놀 계열의 화합물이 많이 추출되는 EtOAc 용매 분획 물에서 우수하게 확인되었으나, 항염 효능은 EtOAc 분획물 보다 hexane 분획물이 더 좋은 항염 효능을 나타내어 추후

Fig. 5.Inhibitory effects of hexane fraction of red beet root on production of inflammatory cytokines in LPS-stimulated RAW264.7 cells.

Cells $\left(2.5 \times 10^{5}\right.$ cells/mL)were pre-incubated for $18 \mathrm{~h}$ and then cells were stimulated with LPS $(1 \mu \mathrm{g} / \mathrm{mL})$ for $24 \mathrm{~h}$ in the presence of hexane and ethyl acetate fractions of red beet root. Suematants were collected, and the (A) TNF-a, (B) IL- 6 and (C) IL-1 $\beta$ concentration in the supernatants was determined by ELISA. Values are the mean \pm SEM of triplicate experiments.

Values with different letters (a-f) are significantly different at $p<0.05$ according to Duncan's multiple range testle range test.

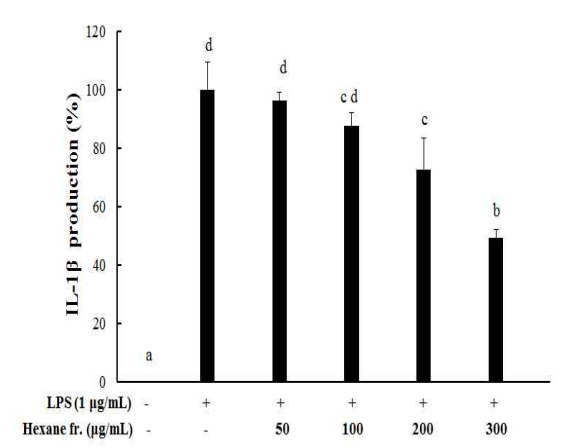


유효성분에 대한 추가적인 연구가 필요할 것으로 사료된 다. 비트 뿌리가 식용으로 다양하게 사용되고 있는 채소류 라는 점을 고려할 때, 안전성이 있으면서 항산화 및 항염증 효과를 가지고 있어 항산화 및 항염 효능을 가지는 건강식 품 소재로서 활용 가능할 것으로 여겨진다.

\section{요 약}

본 연구는 제주도에서 재배된 레드 비트(B. vulagaris) 뿌리의 항산화 및 항염 효과를 알아보기 위하여 $70 \% \mathrm{EtOH}$ 추출물과 순차적 용매 분획물들을 확보하여 총폴리페놀 함량 및 $\mathrm{ABTS}$ 라디칼 소거 활성 측정을 통한 항산화 효능 평가와 대식세포인 RAW264.7 세포에 LPS를 자극한 후 $\mathrm{iNOS} / \mathrm{NO}, \mathrm{COX}-2 / \mathrm{PGE}_{2}$ 및 전염증성 cytokine을 유도하여 염증 억제 효과를 알아보았다. 그 결과, 총 폴리페놀이 37.02 $\mathrm{mg} \mathrm{GAE} / \mathrm{g}$ 로 가장 높게 나온 $\mathrm{EtOAc}$ 분획물이 라디칼 소거 활성도 가장 우수하게 나타났으며 $\left(\mathrm{IC}_{50} ; 42.9 \mu \mathrm{g} / \mathrm{mL}\right)$, 대조 군으로 사용한 $\mathrm{BHT}\left(\mathrm{IC}_{50} ; 57.4 \mathrm{\mu g} / \mathrm{mL}\right)$ 보다 좋은 활성을 보 였다. 항염 활성 분석을 위하여 $\mathrm{NO} / \mathrm{iNOS}, \mathrm{PGE}_{2} / \mathrm{COX}-2$, 및 염증성 cytokine(TNF-a, IL-6, IL-1B)의 생성 억제 효능을 분석한 결과, 총 폴리페놀 함량 결과와는 유의적이지 않게 hexane 분획물이 처리 농도 범위 $(50,100,200,300 \mathrm{\mu g} / \mathrm{mL})$ 에 서 $\mathrm{NO} / \mathrm{iNOS}, \mathrm{PGE}_{2} / \mathrm{COX}-2$, 및 염증성 cytokine 생성을 유의 적으로 억제하였다. $\mathrm{NOS}$ 와 $\mathrm{COX}-2$ 단백질 발현 억제 효과 를 통해 $\mathrm{NO}$ 와 $\mathrm{PGE}_{2}$ 생성 억제에 영향을 끼치고 있음을 확인하였고, 염증성 cytokine 중에는 IL-6의 생성을 가장 강하게 억제함으로써 전체적으로 항염 활성에 영향을 미치 고 있음을 확인할 수 있었다. 이러한 결과들로부터 레드 비트 뿌리의 $\mathrm{EtOAc}$ 분획물에서의 항산화 효능 확인과 hexane 분획물의 세포내 항염 효과를 알 수 있었으며, 향후 유효 물질 동정을 통한 기전 연구를 하는 데 대한 기초자료 로 활용할 수 있을 것이라 사료된다.

\section{감사의 글}

본 연구는 산업통상자원부와 한국산업기술진흥원의 지 역특화산업육성사업으로 수행된 연구결과이며 이에 감사 를 표합니다.

\section{References}

1. Azuma K, Nakayama M, Koshioka M, Ippoushi K, Yamaguchi Y, Kohata K, Yamauchi Y, Ito H, Higashio $\mathrm{H}$ (1999) Phenolic antioxidants from the leaves of
Corchorusolitorius L J Agric Food chem, 47, 3963-3966

2. Kawashima S (1969) The possible role of lipoperoxide in aging. Nagoya $\mathrm{J}$ Med Sci, 32, 303-326

3. Decker EA, Crum AD, Calvert JT (1992) Differences in the antioxidant mechanism of carnosine in the presence of copper and iron. J Agric Food Chem, 40, 756-759

4. Jeong SI, Kim HS, Jeon IH, Kang HJ, Mok JY, Cheon CJ, Yu HH, Jang SI (2014) Antioxidant and anti-inflammatory effects of ethanol extracts from Perilla frutescens. Korean J Food Sci Technol, 46, 87-93

5. Ryu, JH, Ahn H, Kim JY, Kim YK (2003) Inhibitory activity of plant extracts on nitric oxide synthesis in LPS-activated macrophage. Phytother Res, 17, 485-489

6. Hogquist KA, Baldwin TA, Jameson SC (2005) Central tolence: learning self-control in the thymus. Nat Rev Immunol, 5, 772-782

7. Yayeh T, Jung KH, Jeong HY, Park JH, Song YB, Kwak YS, Kang HS, Cho JY, Oh JW, Kim SK, Rhee MH (2012) Korean red ginseng saponin fraction down regulates pro-inflammatory mediators in LPS stimulated RAW264.7 cells and protects mice against endotoxic shock. J Ginseng Res, 36, 263-269

8. Oh SH, Choi SY, Lee NR, Lee JN, Kim DS, Lee SH, Park SM (2014) Cell migration and anti-inflammatory effect of red ginseng extracts fermented with laetiporus sulphureus, J Soc Cosmet Scientists Korea, 40, 297-305

9. Willeaume V, Kryus V, Mijatovic T, Huez G (1996) Turmor necrosis factor-alpha production induced by viruses and by lipopolysaccharides in macrophages: similarities and differences. J Inflamm, 46, 1-12

10. Chang SK, Hyun WC, Kim JH, Ko YJ, Song SM, Ko MH, Lee JC, Kim CS, and Yoon WJ (2015) Anti-inflammatory effects on $80 \%$ ethanol extract and ethyl acetate fraction of Acrosorium yendoi Yamada in murin macrophage RAW264.7 cells. Korean J Plant Res, 28, 574-581

11. Kapadia GJ, Tokuda H, Konoshima T, Nishino H (1996) Chemoprevention of lung and skin cancer by beta vulgaris (beet) root extract. Cancer Lett, 100, 211-214

12. Kanner J, Harel S, Granit R (2001) Betalains-a new class of dietary cationized antioxidants. J Agric Food Chem, 49, 5178-5185

13. Kapadia GJ, Azuine MA, Sridhar R, Okuda Y, Tsuruta A, Ichiishi E, Mukainake T, Takasaki M, Konoshima T, Nishino H, Tokuda H (2003) Chemoprevention of DMBA-induced UV-B promoted, NOR-1-induced TPA promoted skin carcinogenesis, and DEN-induced 
phenobarbital promoted liver tumors in mice by extract of beetroot. Pharmacol Res, 47, 141-148

14. Allegra M, Furtmüller PG, Jantschko W, Zederbauer M, Tesoriere L, Livrea MA, Obinger C (2005) Mechanism of interaction of betanin and indicaxanthin with human myeloperoxidase and hypochlorous acid. Biochem Biophys Res Commun, 332, 837-844

15. Gliszczynska-Swigło A, Szymusiak H, Malinowska $P$ (2006) Betanin, the main pigment of red beet: molecular origin of its exceptionally high free radical-scavenging activity. Food Addit Contam, 23, 1079-1087

16. Jang JR, Kim KK, Lim SY (2009) Effects of solvent extracts from dried beet (Beta vulgaris) on antioxidant in cell systems and growth of human cancer cell lines. J Korean Soc Food Sci Nutr, 38, 832-838

17. Zhang Q, Zhang J, Shen J, Silva A, Dennis DA, Barrow CJ (2006) A simple 96-well microplate method for estimation of total polyphenol content in seaweeds. J Appl Phycol, 18, 445-450

18. Re R, Pellegrini N, Proteggente A, Pannala A, Yang M, Rice-Evans C (1999) Antioxidant activity applying an improved ABTS radical cation decolorization assay. Free Radic Biol Med, 26, 1231-1237

19. Amano F, Noda $T$ (1995) Improved detection of nitric oxide radical production in an activated macrophage culture with a radical scavenger, carboxy PTIO and griess reagent. FEBS Lett, 368, 425-428

20. Chei HJ, Lee HJ, Shin BG, Lee IC, Hwang JS (2004) Deoxypodophyllotoxin reduces skin pigmentation of brown guinea pigs. Planta Med, 70, 378-380

21. Giovannini C, Scazzocchio B, Vari R, Santangelo C, D'Archivo M, Masella R (2007) Apoptosis in cancer and atherosclerosis: polyphenol activities. Ann Ist Super Sanita, 43, 406-416

22. Imai J, Ide $\mathbf{N}$, Nagae $\mathrm{S}$, Moriguchi $\mathrm{T}$, Matsuura $\mathrm{H}$, Itakura Y (1994) Antioxidant and radical scavenging effects of aged garlic extract and its constituents. Plant Med, 60, $417-420$
23. Rice Evans CA, Miller NJ, Paganga G (1997) Antioxidant properties of phenolic compounds. Trends Plant Sci, 2, 152-159

24. Lee JH, Chin KB (2012) Evaluation of antioxidant activities of red beet extracts, and physicochemical and microbial changes of ground pork patties containing red beet extracts during refrigerated storage. Korean J Food Sci An, 32, 497-503

25. Arnao MB (2000) Some methodological problems in the determination of antioxidant activity using chromogen radicals: a practical case. Trends Food Sci Technol, 11, 419-421

26. Lee SH, Kim NS, Choi BK, Park YH, Kim JB, Jang HH, Hwang YJ, Choe JS, Lee SH (2017) Evaluation of antioxidant, anti-inflammatory, antithrombotic, and antiobesity activities in cultured edible plants to increase farm income. Korean J Community Living Sci, 28, 29-43

27. Tezuka Y, Irikawa S, Kaneko T, Banskota AH, Nagaoka T, Xiong Q, Hase K, Kadota S (2001) Screening of Chinese herbal drug extracts for inhibitory activity on nitric oxide production and identification of an active compound of Zanthoxylum bungeanum J Ethnopharmacol, 77, 209-217

28. Kim RG, Shin KM, Chun, SK, Ji SY, Seo SH, Park HJ, Choi JW, Lee KT (2002) In vitro anti-inflammatory activity of the essential oil from Ligularia fischeri var. spiciformis in murine macrophage RAW264.7 cells. J Pharm Soc Korea, 46, 343-347

29. Kim SS, Park KJ, An HJ, Choi YH (2016) Citrus platymamma inhibits the expression of pro-inflammatory cytokines, inducible nitric oxide synthase, and cyclooxygenase-2 in RAW264.7 macrophage. Korean J Food Preserv, 23, 1026-1032 